九州大学学術情報リポジトリ

Kyushu University Institutional Repository

\title{
Rearing Of Flea Larvae On Various Diets
}

Yasumatsu, Keizo

Entomological Laboratory, Department of Agriculture, Kyushu University

https://doi.org/10.5109/22616

出版情報 : 九州大学大学院農学研究院紀要. 9 (2)，pp.121-126，1949-05. Kyushu University バージョン：

権利関係 : 
Journal of the Faculty of Agriculture, Kyūshū University, Vol. 9, No. 2

May $31,1949^{\prime}$

\title{
REARING OF FLEA LARVAE ON VARIOUS DIETS*
}

\author{
KeIzô Yasumatsu
}

As regards the rearing of fleas, a considerable amount of general information has been accumulated during the past 250 years. But knowledge is scarce particularly about the kind of food used by flea larvae. The following is a review of diets of flea larvae which were used by various authors.

Cestone, J., 1699: the bran-like substance which sticks in the combs when puppies are combed to take out the fleas.

Strickland, C., 1913 : refuse from rat cages consisting mainly of dried grain, excreta, gravel, straw, etc. (" rubbish").

Bacot, A. W., 1914: the faeces of the adult flea or anal discharges.

Bacot, A. W. and W. G. Ridewood, 1914: organic matter in the lair of the host, on the dust that collects on the ground in its proximity and the excreta of the adult flea or particles of dried blood.

Bishop, F. C., 1915 : partly of blood voided by the adult and partly of particles of animal or vegetable origin.

Lyon, H., 1915: floor sweepings and dried blood.

Illingworth, J. F., 1915: dried blood particles in the dust and the excreta of the adult flea.

Sikes, E. K., 1930: dried blood (human or rabbit) ground up finely.

Sikes, E. K., 1931: dried blood, nest material, flea faeces, albumen.

\footnotetext{
* Published with the aid of a grant from the Ministry of Education in Japan.
} 
Leeson, H. S., 1932: finely ground dried ox-liver.

Hopkins, G. H. E., 1935; unsterilised bran or maize meal with a pinch of dried ox-blood.

Yasumatsu, K., 1946: dust under the Japanese "Tatami".

The foreguing papers present considerable information on diets of flea larvae; but only Sikes' (1931) work studies the effect of various diets upon the growth of flea larvae. The chief object of the present experiments was to make a preliminary study of the growth-rate of flea larvae on various diets in order to determine the more corvenient or economic diets which may be used easily in rearing experiments.

I should like to thank Professor Teiso Esaki, of the Kyushu University, for his kind help and advice during the course of the present experiments, and Doctor Joseph Bequaert, of the Museum of Comparative Zoölogy of Harvard College, for his criticism and and kindness in reading through this manuscript.

\section{Material AND Method}

The Heas, Ceratophyllus cheopis Rothschild, were bred in the laboratory on a rat. The rat was combed carefully and given sterilised bedding, before being provided with identified specimens of $C$. cheopis. Samples of adult fleas were taken frequently from the bed of the rat and identified to make sure that the culture remained pure. Pregnant female fleas were taken from the bed and put in a small glass cylinder placed on black paper. The fleas were left in this for 24 hours, and then returned to the rat, a supply of eggs having been laid in the meantime. The eggs were easy to see and count on black paper. From these eggs 0 to 24 hours old flea larvae were easily collected. In all cases 0 to 24 hours old unfed larvae were used in the present experiments. The flea larvae were bred in glass bottles which were previously provided with sawdust and the following diets; and only those which reached adult stage were counted. The experiments were carried out at room temperature and humidity, but both seemed to make little difference to the survival of the larvae, only affecting the rate of development so far as the present experiments were concerned. 
1. Flour of miscellaneous cereals and beans (A).

2. Excrements of silk-worms, dried and powdered (B).

3. Silk-worm pupae, dried and powdered (C).

4. Ox-liver, dried and powdered (L).

5. Excrements of rats, dried and powdered (M)

6. Bran of rice $(\mathrm{N})$.

7. Ox-blood, dried and powdered (bl).

.8. Haemoglobin $(\mathrm{H})$.

9. Dust under the Japanese "Tatami" or dust on the floor (D).

10. Lactose, vitamins $\mathrm{A}, \mathrm{B}, \dot{\mathrm{C}}, \mathrm{D}$ and liver-oil (powdered) (K).

\section{RESUlts AND CONSIDERATIONS}

In order to determine whether dietal reaction would produce a differential effect upon the growth of flea larvae, experiments were conducted in which 7210 to 24 hours old larvae were reared to maturity on diets of different types. Larvae were supplied with abundance of diets for food. The results of all experiments are summarised in tables 1 to 3 .

Table 1. Effect of breeding flea larvae on various diets at room temperature and humidity. Cases fed on single diets.

$\begin{array}{cccc}\text { Diets } & \begin{array}{c}\text { Newly hatched } \\ \text { larvae used }\end{array} & \begin{array}{c}\text { Larvae which reached } \\ \text { adult stage }\end{array} & \begin{array}{c}\text { Larvae which reached } \\ \text { adult stage }(\%)\end{array} \\ \text { A } & 30 & 11 & 36.7 \\ \text { B } & 30 & 0 & 0.0 \\ \text { bl } & 14 & 4 & 28.6 \\ \text { C } & 20 & 5 & 25.0 \\ \text { D } & 25 & 23 & 92.0 \\ \text { H } & 20 & 0 & 0.0 \\ \text { K } & 20 & 0 & 0.0 \\ \text { L } & 20 & 0 & 0.0 \\ \text { M } & 20 & 19 & 95.0\end{array}$

Table 2. Effect of breeding flea larvae on various diets at room temperature and humidity. Cases fed on two mixed diets.

$\begin{array}{cccc}\text { Diets } & \begin{array}{c}\text { Newly hatched } \\ \text { larvae used }\end{array} & \begin{array}{c}\text { Larvae which reached } \\ \text { adult stage }\end{array} & \begin{array}{c}\text { Larvae which reached } \\ \text { adult stage }(\%)\end{array} \\ \mathrm{A}+\mathrm{B} & 30 & 11 & 36.7 \\ \mathrm{~A}+\mathrm{bl} & 32 & 31 & 96.9 \\ \mathrm{~A}+\mathrm{C} & 30 & 14 & 46.7\end{array}$




$\begin{array}{lrrr}\text { A +K } & 20 & 6 & 30.0 \\ \mathrm{~A}+\mathrm{L} & 20 & 0 & 0.0 \\ \mathrm{~A}+\mathrm{M} & 20 & 15 & 75.0 \\ \mathrm{~A}+\mathrm{N} & 20 & 5 & 25.0 \\ \mathrm{~B}+\mathrm{bl} & 30 & 18 & 60.0 \\ \mathrm{~B}+\mathrm{C} & 30 & 11 & 36.7 \\ \mathrm{~B}+\mathrm{I} & 30 & 0 & 0.0 \\ \mathrm{bl}+\mathrm{C} & 20 & 7 & 28.6 \\ \mathrm{bl}+\mathrm{K} & 20 & 1 & 5.0 \\ \mathrm{~b}+\mathrm{L} & 20 & 1 & 5.0 \\ \mathrm{bl}+\mathrm{M} & 20 & 0 & 0.0 \\ \mathrm{bl}+\mathrm{N} & 20 & 0 & 0.0 \\ \mathrm{C}+\mathrm{K} & 20 & 3 & 15.0 \\ \mathrm{C}+\mathrm{M} & 20 & 18 & 90.0 \\ \mathrm{C}+\mathrm{N} & 20 & 0 & 0.0 \\ \mathrm{~K}+\mathrm{M} & 20 & 0 & 0.0 \\ \mathrm{~K}+\mathrm{N} & 20 & 0 & 0.0 \\ \mathrm{~L}+\mathrm{M} & 20 & 15 & 75.0 \\ \mathrm{~T}+\mathrm{N} & 20 & 0 & 0.0 \\ \mathrm{M}+\mathrm{N} & 20 & 14 & 70.0\end{array}$

Table 3. Effect of breeding flea larvae on various diets at room temperature and humidity.

\section{viets}

A

$A+B$

$\mathrm{A}+\mathrm{C}$

$\mathrm{A}+\mathrm{bl}$

$B+b 1$

$\mathrm{B}+\mathrm{C}$

D)

$\mathrm{A}+\mathrm{K}$

$\mathrm{A}+\mathrm{M}$.

$A+N$

bi

bl $+\mathrm{C}$

bl $+\mathrm{K}$

bl +1 .

c.

$\mathrm{C}+\mathrm{K}$

C. $+\mathrm{M}$

L. $+\mathrm{M}$

$\mathrm{M}$

$\mathrm{M}+\mathrm{N}$
Duration of larval and pupal periods taken together in days

Minimum

.3.3

38

33

24

23

34

it.

46

$3 y$.

(i)

bis

$4 y$

88

50

39

40

40

24

\section{Maximum Average}

81

126

48

78

125

93

40

91

88

98

67

99

y4

51

50

65

66

77

43.3

93.2

36.0

30.9

31.2

44.2

27.3

75.8

51.2

74.0

64.0

73.5

82.0

49.0

89.2

50.3

41.8

46.1

45.6

49.1
Mean

relative humidity
Mean temperature

("C)

$\begin{array}{rr}82.7 & 26.0 \\ 82.8 & 22.6 \\ 82.5 & 26.5 \\ 81.3 & 26.1 \\ 81.0 & 26.1 \\ 82.7 & 25.7 \\ 81.2 & 26.9 \\ 81.8 & 17.1 \\ 82.3 & 18.5 \\ 80.9 & 16.8 \\ 82.0 & 19.1 \\ 81.9 & 17.1 \\ 80.8 & 17.6 \\ 83.6 & 20.4 \\ 79.8 & 15.5 \\ 83.5 & 15.5 \\ 83.8 & 19.6 \\ 83.5 & 19.3 \\ 83.7 & 19.3 \\ 81.1 & 17.0\end{array}$


Table 4. Effect of breeding flea larvae on various foods at 80 and 90 $\left(^{*}\right)$ percentages of relative humidity (Temperature $21^{\circ} \mathrm{C}$ )

Selerted from E. K. Sikes, 1931;

Diets
* Rabbit blood
Rabbit blood and sand 1
Rabbit blood on cloth 1
* Rat blood and sand
* Human blood on cloth
Flea faeces and sand
Flea faeces on cloth 1

Newly hatched
larvae used
27
25
25
16
25
25
35

Larvae which
reached
adult stage
15
17
15
9
13
15
18

Larvae which
reached
adult stage $(\%)$
55.5
68.0
60.0
56.3
52.0
60.0
72.0

The present experiments indicate clearly that there are great differences in the percentage of flea larvae which reached adult stage among nine kinds of a single diet and twenty-three kinds of mixed diets. It is of interest to contrast the present results with those of similar experiments made by Sikes in 1931 (see table 4 . The relatively better development of larvae and pupae, as shown by the percentage reaching the adult stage, or diets of dust under the Japanese "Tatami", or dust on the floor, or excements of rats (dried and powdered) shows that such single diets are clearly sufficient and satisfactory for this flea. On the other hand, the relatively poor development or high mortality of larvae and pupae fed on other single diets, as well as on a number of mixed ones, indicate that even the ox-liver and blood. hitherto known as the best diets, are not as good for the post embryonic growth of fied larvae as the single diets mentioned above. The duration of larval and pupal periods taken together, from the time of hatching from the egg to the emergence of the adult, seems to vary greatly with the kind of diet. The duration varies greatly both in the minimum and maximum number of days taken to complete the larval and pupal stages; but only the minimum number of days is most significant in the determination of dietal reaction upon the growth of flea larvae and pupae. Therefore there is a certain parallelism between the duration of the larval and pupal periods and the percentage of larvae which reach the adult stage. The experiments show that the best results are obtained in breeding flea larvae with dust under the Japanese "Tatami" or dust on the floor and excrements of ex- 
crements of rats, dried and powdered. From the present experiments I would emphasize the dust and excrements of rats are the most convenient and economic diets which may be used every. where easily in rearing experiments.

\section{LITERATURE}

(Literature published after the year 1941 was not accessible to me owing to the war)

Bacot, A. W. and W. G. Ridewood 1914 Observations on the larvae of Heas. Parasit., 8: 157-175.

Bacot, A. W. 1914 A study of the bionomics of the common rat fleas and other species associated with human habitations, with special reference to the influence of temperature and humidity at various periods of the life-bistory of the insect. Jour. Hygiene, Plague suppl., 3: 447-654.

Bishop, F. C. 1915 Fleas. U. S. Dept. Agr, Washington, D.C., Bull. 248.

Hopkins, G. H. E. 1935 Some observations on the bionomics of fleas in the East Africa. Parasit., $27: 480-488$.

Illingworth, J. F. 1915 Hen fleas, Xestopsylla gallinacea, Westw. Hawaiian Forester \& Agriculturist, 12: 130-132.

Leeson, H. S. 1932 Methods of rearing and maintaining large stocks of fleas and mosquitoes for experimental purposes. Bull. Ent Res., 23 : 25-31.

Lyon, H. 1915 Notes on the cat flea (Ctenocophalus felis, Bouche). Psyche, 22 : 124-132.

Newstead, R. and A. M. Evans 1921 Report on rat.flea investigation. Ann. Trop. Med. \& Parasit., 15: 287-300.

Sharif, M. 1937 On the life history and the biology of the rat-flea, Nosopsyllus fascintus (Bosc). Parasit, 29: 225-238.

Sikes, E. K. 1930 Larvae of Ceratophyllus wickhami and other species of fleas. Parasit., 22 : 242-259.

Sikes, E. K. 1931. Notes on breeding fleas, with reference to the bumidity and feering. Parasit., 23 : 243-249

Striciliand, C. 1913 The biology of Corntophyllus fitsriatus Bosc., the common rat tlea of Great Britain. 42nd Ann. Rep. Local Govt., 1912-13, Suppl. Appendix B : $401-412$.

Yasumatsu, K. 1946 An account on the fleas (in Japanese). Fukuoka. 